\title{
THE EXPEDIENCY OF STARTING THE SALE OF LAND IN UKRAINE IN AN ECONOMIC DOWNTURN
}

Постановка проблеми. Сільськогосподарська земля України є надзвичайно цінним ресурсом, який забезпечує функціонування української нації та української держави. Розвиток ринку землі сільськогосподарського призначення здійснює безпосередній вплив на соціально-економічні та суспільно-політичні тенденції розвитку нашої країни. Українська земельна реформа $є$ однією 3 найбільш складних і тривалих трансформацій у світовій практиці. При цьому ключові аспекти ії реалізації, зокрема можливість передачі права власності на землю сільськогосподарського призначення, досі залишаються невирішеними. Сільськогосподарські підприємства $є$ головними користувачами сільськогосподарських угідь. Інституціоналізація процесів руху землі сільськогосподарського призначення сьогодні охоплює комплексне нормативно-правове забезпечення, систему міжнародних та національних стандартів і вироблену практику обслуговування запитів користувачів інформації щодо відображення земельно-майнових та господарських процесів у первинних документах та звітності. Проте фрагментарність реформи не дозволяє повною мірою охопити і комплексно відобразити усі господарські та цивільно-правові аспекти землекористування сільськогосподарських підприємств. Саме тому це вимагає подальших досліджень і наукових пошуків.

Аналіз останніх досліджень i публікацій. Особливості розвитку ринку землі сільськогосподарського призначення опрацьовано у значній кількості праць. Питання теоретикометодичного та інституційного забезпечення регулювання земельних відносин у сільському господарстві стали предметом наукового пошуку В. Г. Андрійчука, Ш. І. Ібатулліна, В. М. Заяця, М. В. Зось-Кіора, І. В. Кошкалди, Ю. Я. Лузана, Ю. О. Лупенка, П. О. Масляка, А. Я. Сохнича, В. М. Трегобчука, М. М. Федорова, О. В. Ходаківської, П. Г. Шищенко та ін.

Проте, проаналізувавши праці науковців, потрібно звернути увагу на те, що вивчення теоретичних та практичних аспектів формування повноцінного ринку землі в Україні не можна назвати достатнім, а тому вони потребують подальшого опрацювання.

Постановка завдання. Метою статті $€$ характеристика сучасних теоретичних і практичних аспектів функціонування ринку землі сільськогосподарського призначення в Україні у другій половині 2021 року.

Виклад основного матеріалу дослідження. Початок продажу землі сільськогосподарського призначення $€$ надзвичайно важливим як для майбутнього України, так і для майбутнього європейського континенту і світової продовольчої безпеки.

Згідно розділу І статті 13 Конституції України, «земля, ..., яка знаходяться в межах території України, ... є об’єктом права власності Українського народу. Кожний громадянин має право користуватися природними об'єктами права власності народу (уточнення - має право користуватися, а не бути безроздільним одноосібним власником. Тобто, український народ, як справжній власник землі, делегує право громадянину - власнику пая чи іншого земельного наділу сільськогосподарського призначення - користуватися землею, яка належить українському народу в інтересах українського народу i, паралельно, у власних інтересах - авт.). Згідно розділу І статті 14 Конституції України, «земля є основним національним багатством, що перебуває під особливою (підкреслю - «особливою» - авт.) охороною держави» [1]. Тому держава повинна поновити мораторій на продаж землі та забезпечити новий, оптимальний для продажу землі час через:

- досягнення максимально-можливої ціни продажу землі;

- забезпечення мінімально можливого кола власників землі сільськогосподарського призначення, у яких виникне потреба продати землю; 
- створення умов для збереження реальної, а не номінальної, власності над українською землею у громадян України.

Максимальна ціна землі досягається в умовах економічного зростання у країні, зниження боргового навантаження на економіку, забезпечення соціально-економічної та суспільно-політичної стабільності.

Протягом двох років (вересень 2019 - березень 2021 року) відбувся негативний тренд у динаміці економічного зростання.

3 даних рис. 1 можемо зробити висновок про те, що із першого кварталу 2016 року і до кінця 2019 року відбувалось динамічне економічне зростання ВВП протягом шістнадцяти кварталів без пауз, проте, починаючи із першого кварталу 2020 року і по перший квартал 2021 року відбувається безупинне щоквартальне падіння ВВП України.

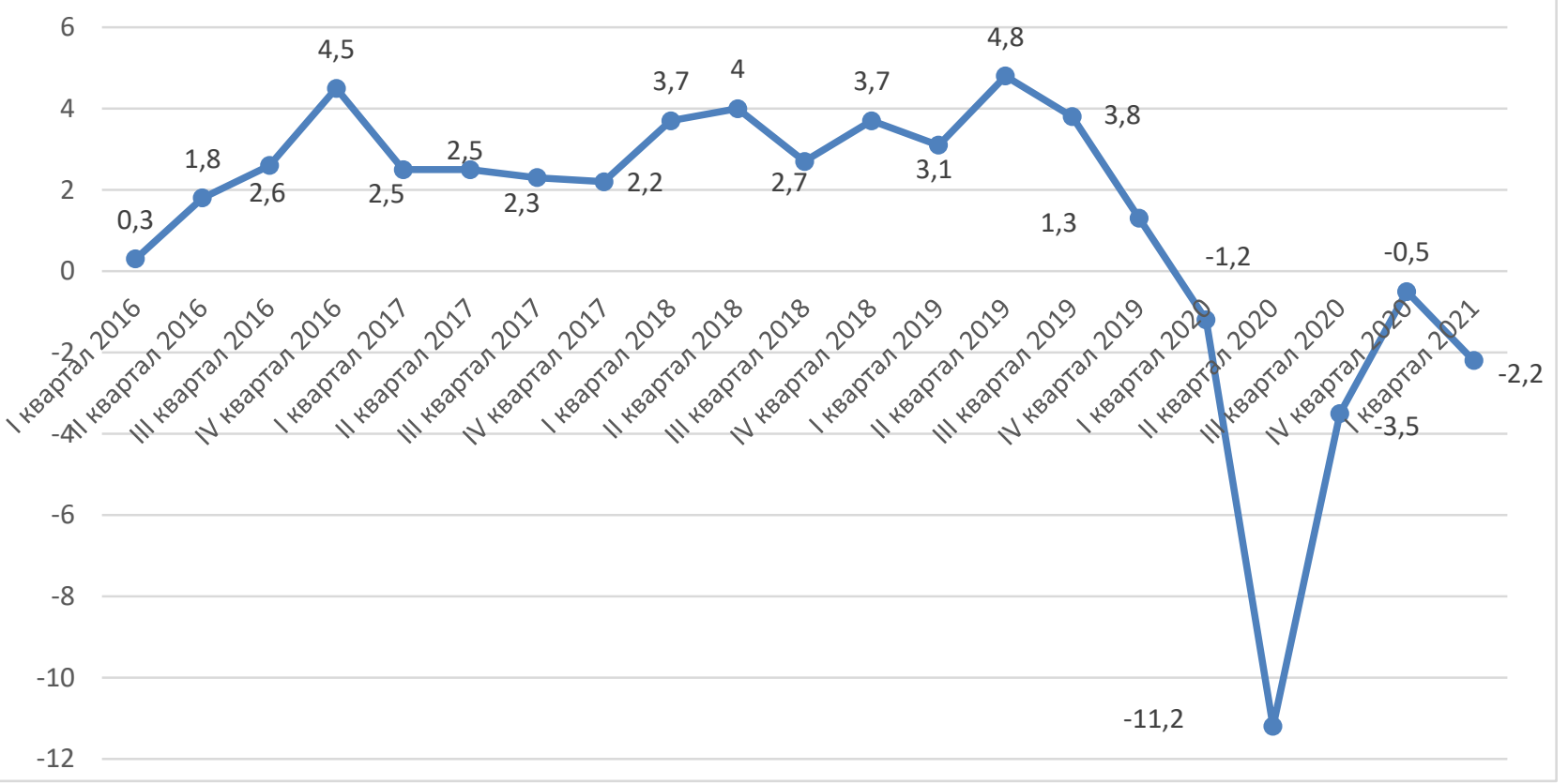

Рис. 1. 3міна реального валового внутрішнього продукту (ВВП) в 2016-2021 роках

Джерело: [2] (у \% до відповідного кварталу попереднього року)

Слід зазначити, що із зміною Президента України, яке відбулася у II кварталі 2019 року і, як наслідок, дострокових виборів депутатів до Верховної Ради України і, відповідно, зміною складу міністрів Кабінету Міністрів України, що відбулися у III кварталі 2020 року, проявилась значна корекція економічної політики. Своєю чергою, це здійснило негативний вплив на економіку та знайшло своє відображення у проявленні кризових явищ у багатьох секторах економіки, появі від'ємної динаміки економічного зростання в Україні та падінні реального ВВП і переходу динаміки зростання ВВП на негативні показники з початком 2020 року, хоча, по інерції, у III та IV кварталах 2019 року ВВП України ще зростав. Це добре проілюстровано на рис. 2-3.

Отже, ґрунтуючись на даних рис. 2, можна стверджувати, що зміна уряду у третьому кварталі 2019 року зумовила те, що економічне зростання у третьому кварталі у порівнянні з другим знизилось з 4,8\% до 3,8\%, а у четвертому кварталі по відношенню до третього кварталу 2019 року склало всього $1,4 \%$, тобто зменшилось у 3,43 раза $(4,8 / 1,4=3,43)$ або на понад $70 \%((4,8-1,4) / 4,8 \times 100 \%=$ 70,83\%) порівняно з другим кварталом 2019 року. Всього через неповних пів року після зміни керівництва країни новому уряду вдалось зупинити економічне зростання і забезпечити безперервне економічне падіння. Слід зазначити, що у третьому та четвертому кварталах 2019 року і у першому кварталі 2020 року пандемія Covid-19 не справляла на економіку ніякого впливу, отже, економічне падіння зумовило або неефективне управління економікою та карантином, або цілеспрямовані дії державного механізму щодо зупинки економічного зростання та підтримки динаміки економічного падіння, або обидва аспекти спільно. 


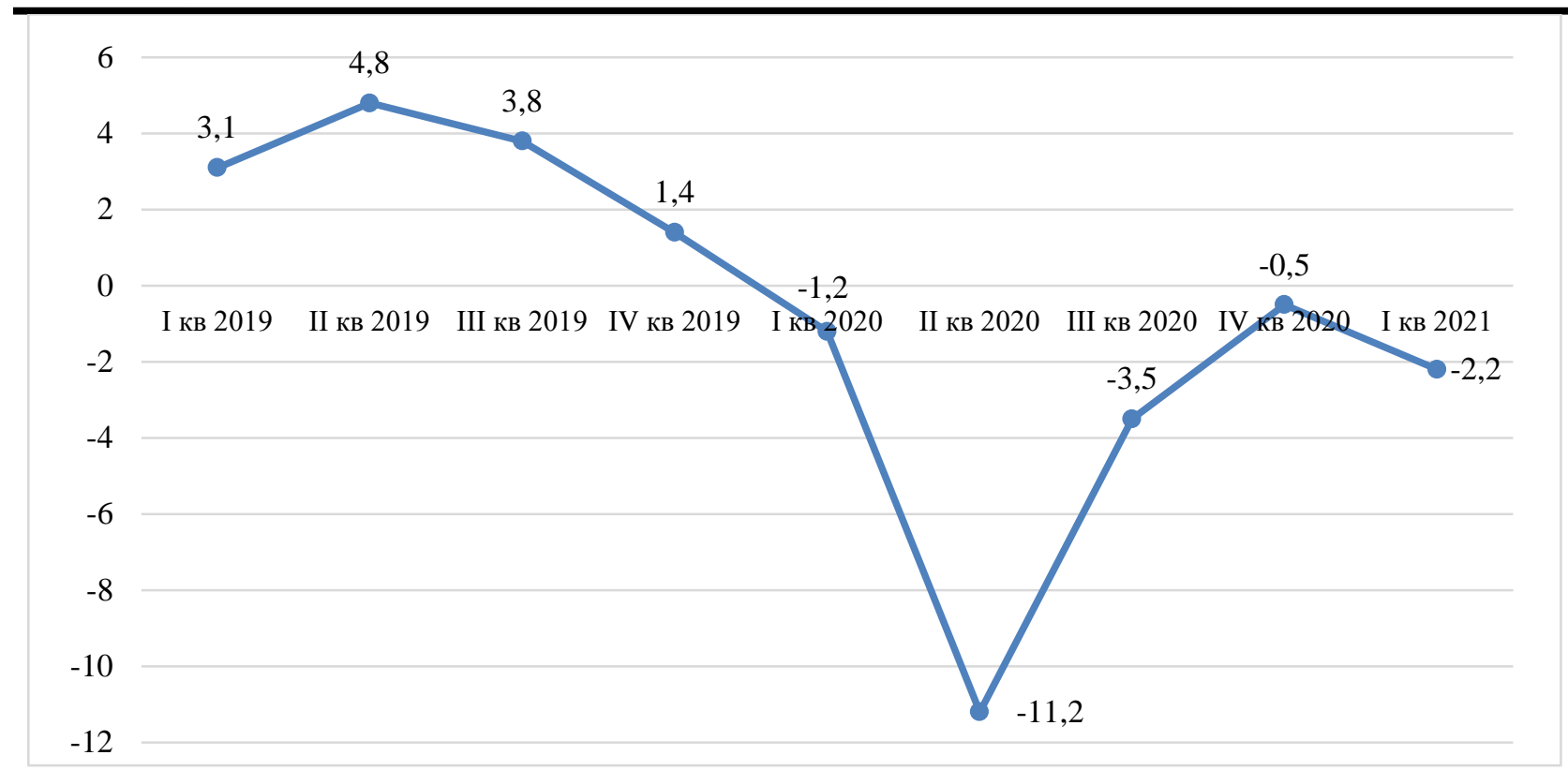

Рис. 2. 3міна обсягу ВВП в 2019-2021 роках

(у \% до відповідного кварталу попереднього року)

Джерело: побудовано автором на основі даних рис. 1

Також протягом другої половини 2019 року - першої половини 2021 року значно прискорилось зростання зовнішньої заборгованості країни.

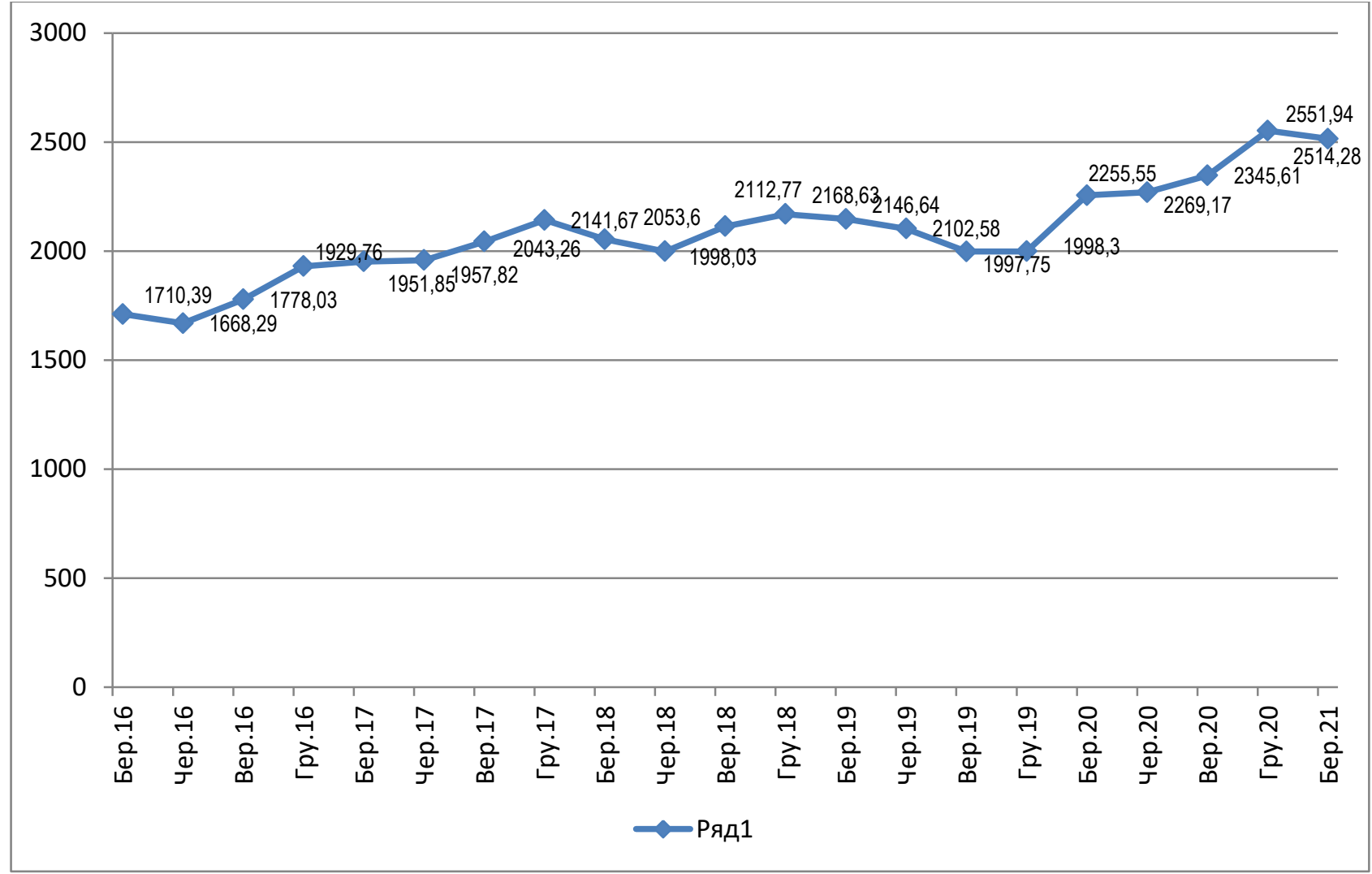

Рис. 3. Динаміка зовнішньої заборгованості протягом

Джерело: [3] березня 2016 - березня 2021 року

Темпи зростання і приросту з березня 2016 року по березень 2021 року проаналізовано у табл. 1., рис. 4 - 5 . 
Темпи зростання і приросту з березня 2016 року по березень 2021 року

\begin{tabular}{|c|c|c|c|c|c|c|c|c|}
\hline \multirow[b]{2}{*}{ Рік } & \multirow[b]{2}{*}{$\begin{array}{c}\text { Державний і } \\
\text { гарантований } \\
\text { державою борг, } \\
\text { млрд грн }\end{array}$} & \multicolumn{2}{|c|}{$\begin{array}{l}\text { Абсолютні } \\
\text { прирости }\end{array}$} & \multicolumn{2}{|c|}{$\begin{array}{c}\text { Темпи } \\
\text { зростання }\end{array}$} & \multicolumn{2}{|c|}{ Темпи приросту } & \multirow[b]{2}{*}{$\begin{array}{c}\text { Абсолютний } \\
\text { вміст } 1 \% \\
\text { приросту }\end{array}$} \\
\hline & & 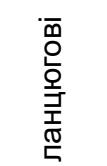 & 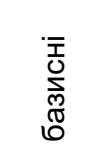 & 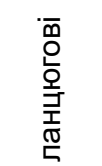 & $\begin{array}{l}\overline{\bar{T}} \\
\stackrel{0}{\grave{D}} \\
\stackrel{0}{0}\end{array}$ & 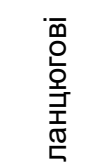 & 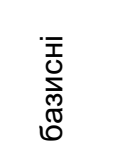 & \\
\hline Березень 2016 & 1710,39 & & & 1 & 0,876 & & & \\
\hline Червень 2016 & 1668,29 & $-42,1$ & $-283,6$ & 0,975 & 0,855 & $-0,025$ & $-0,145$ & 17,10 \\
\hline Вересень 2016 & 1778,03 & 109,7 & $-173,8$ & 1,066 & 0,911 & 0,066 & $-0,089$ & 16,68 \\
\hline Грудень 2016 & 1929,76 & 151,7 & $-22,1$ & 1,085 & 0,989 & 0,085 & $-0,011$ & 17,78 \\
\hline Березень 2017 & 1951,85 & 22,1 & 0,0 & 1,011 & 1,000 & 0,011 & 0,000 & 19,30 \\
\hline Червень 2017 & 1957,82 & 6,0 & 6,0 & 1,003 & 1,003 & 0,003 & 0,003 & 19,52 \\
\hline Вересень 2017 & 2043,26 & 85,4 & 91,4 & 1,044 & 1,047 & 0,044 & 0,047 & 19,58 \\
\hline Грудень 2017 & 2141,67 & 98,4 & 189,8 & 1,048 & 1,097 & 0,048 & 0,097 & 20,43 \\
\hline Березень 2018 & 2053,6 & $-88,1$ & 101,8 & 0,959 & 1,052 & $-0,041$ & 0,052 & 21,42 \\
\hline Червень 2018 & 1998,03 & $-55,6$ & 46,2 & 0,973 & 1,024 & $-0,027$ & 0,024 & 20,54 \\
\hline Вересень 2018 & 2112,77 & 114,7 & 160,9 & 1,057 & 1,082 & 0,057 & 0,082 & 19,98 \\
\hline Грудень 2018 & 2168,63 & 55,9 & 216,8 & 1,026 & 1,111 & 0,026 & 0,111 & 21,13 \\
\hline Березень 2019 & 2146,64 & $-22,0$ & 194,8 & 0,990 & 1,100 & $-0,010$ & 0,100 & 21,69 \\
\hline Червень 2019 & 2102,58 & $-44,1$ & 150,7 & 0,979 & 1,077 & $-0,021$ & 0,077 & 21,47 \\
\hline Вересень 2019 & 1997,75 & $-104,8$ & 45,9 & 0,950 & 1,024 & $-0,050$ & 0,024 & 21,03 \\
\hline Грудень 2019 & 1998,3 & 0,5 & 46,5 & 1,000 & 1,024 & 0,000 & 0,024 & 19,98 \\
\hline Березень 2020 & 2255,55 & 257,3 & 303,7 & 1,129 & 1,156 & 0,129 & 0,156 & 19,98 \\
\hline Червень 2020 & 2269,17 & 13,6 & 317,3 & 1,006 & 1,163 & 0,006 & 0,163 & 22,56 \\
\hline Вересень 2020 & 2345,61 & 76,4 & 393,8 & 1,034 & 1,202 & 0,034 & 0,202 & 22,69 \\
\hline Грудень 2020 & 2551,94 & 206,3 & 600,1 & 1,088 & 1,307 & 0,088 & 0,307 & 23,46 \\
\hline Березень 2021 & 2514,28 & $-37,7$ & 562,4 & 0,985 & 1,288 & $-0,015$ & 0,288 & 25,52 \\
\hline
\end{tabular}

Джерело: побудовано автором на основі даних рис. 3

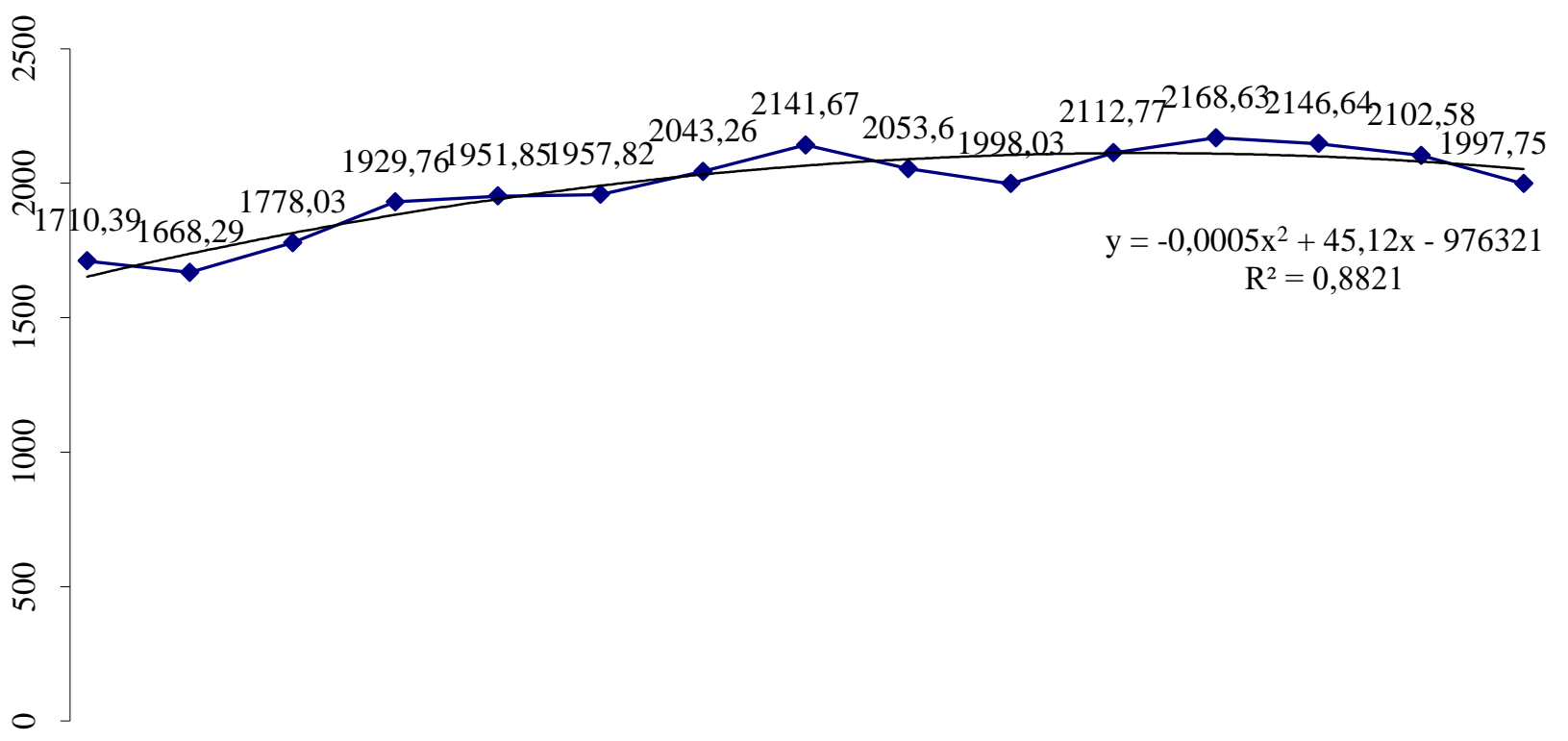

Рис. 4. Поліноміальна функція зміни розміру державного та гарантованого державою боргу з березня 2016 року по вересень 2019 року

Джерело: побудовано автором на основі даних табл. 1 


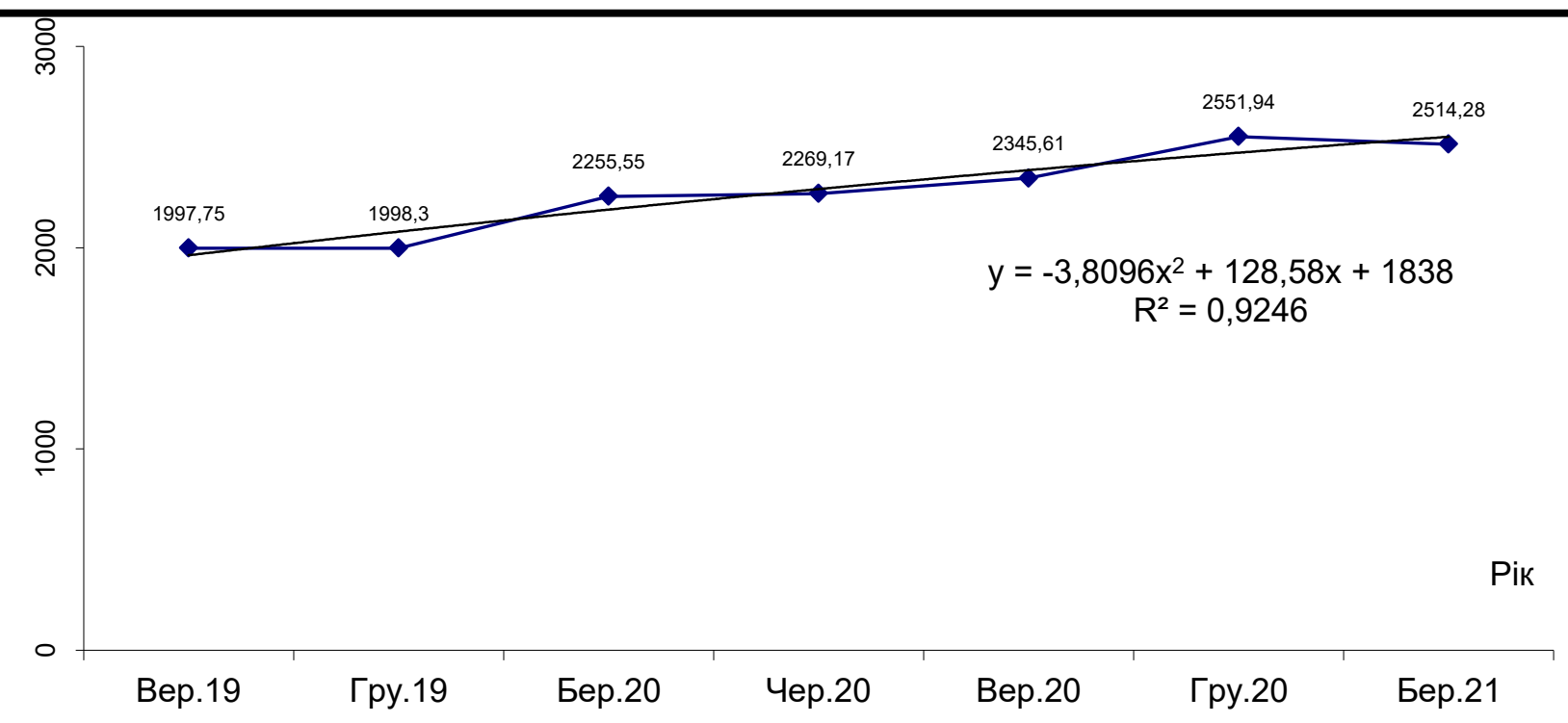

Рис. 5. Поліноміальна функція зміни розміру державного та гарантованого державою боргу з вересня 2019 року по березень 2021 року

Джерело: побудовано автором на основі даних табл. 1

Аналіз даних рис. 4-5 ілюструє різну направленість трендів зміни розміру державного та гарантованого державою боргу у період з березня 2016 року по вересень 2019 року та з вересня 2019 року по березень 2021 року.

Середньоквартальний абсолютний приріст державного і гарантованого державою боргу розрахуємо за формулою (1):

$$
\Delta y=\frac{y_{n}-y_{0}}{n-1}
$$

де $y_{n}, y_{0}$-відповідно кінцевий і початковий рівні ряду;

$n-$ кількість рівнів ряду.

Середньоквартальний абсолютний приріст державного і гарантованого державою боргу 3 березня 2016 року по вересень 2019 року склав:

$$
\Delta y=\frac{1997.8-1710.4}{15-1}=\frac{287.4}{14}=20.53 \text { млрд грн }
$$

Середньоквартальний абсолютний приріст державного і гарантованого державою боргу 3 вересня 2019 року по березень 2021 року склав:

$$
\Delta y=\frac{2514,3-1997.8}{7-1}=\frac{516.5}{6}=86.09 \text { млрд грн }
$$

Середньоквартальний коефріцієнт зростання $\left({ }^{\overline{T p}}\right)$ розрахуємо за формулою (2):

$$
\overline{T p}^{n-1} \sqrt{\frac{y_{n}}{y_{1}}}=
$$

Середньоквартальний коефіцієнт зростання з березня 2016 року по вересень 2019 року склав:

$$
\bar{T} p=1,012
$$

Середньоквартальний коефіцієнт приросту розрахуємо за фрормулою (3):

$$
\bar{T} n p=\bar{T} p-1
$$


Середньоквартальний коефріцієнт приросту з березня 2016 року по вересень 2019 року склав:

$$
\bar{T} n p=1,0112-1=0,0112 \text { або } 1,12 \%
$$

Середньоквартальний коефіцієнт зростання з вересня 2019 року по березень 2021 року склав:

$$
\bar{T} p=1,0391
$$

Середньоквартальний коефріцієнт приросту з вересня 2019 року по березень 2021 року склав:

$$
\operatorname{Tnp}=1,0391-1=0,0391 \text { або 3,91\% }
$$

Отже, приріст державного та гарантованого державою боргу з вересня 2019 року по березень 2021 року збільшився у 3,5 раза $(3,91 / 1,12=3,5)$ порівняно з періодом з березня 2016 року по вересень 2019 року, що є надзвичайно негативною тенденцією.

У 2020 році відбулося падіння ВВП на $4 \%$ і у першому кварталі 2021 року зниження ВВП склало 2\%; дефріцит державного бюджету в 2020 році став найбільшим за останні 10 років і склав 218 млрд грн або $5,2 \%$ від ВВП (що майже вдвічі більше граничного рівня у $3 \%$ ); державний та гарантований державою борг з березня 2016 року по вересень 2019 року зріс на 287,4 млрд грн, а з вересня 2019 року по березень 2021 року - на 516,5 млрд грн, тобто темп його зростання пришвидшився у 3,5 раза і середньозважена дохідність розміщених у I кварталі 2021 року на первинному ринку ОВДП досягла рекордних понад $11 \%$, що, своєю чергою, призвело до збільшення загального обсягу державного і гарантованого державою боргу по відношенню до ВВП з 50\% у 2019 році [4] до 60,9\% у 2020 році [5]; чистий відтік прямих іноземних інвестицій за 2020 рік склав 868,2 млн дол. [6].

Варто зазначити, що і забезпечення мінімально можливого кола продавців землі також не може бути підтверджене.

Індекс приросту споживчих цін у першому півріччі в 2021 році став найвищим з 2016 року і склав 8,3\% [7]; кількість отримувачів субсидій зменшилась у рази (станом на грудень 2017 року 7 мільйонів українських домогосподарств мали субсидії, а 2021 року їх поменшало до 3 мільйонів [8]); безробіття зросло з 8,5\% у 2019 році до 9,9\% у 2020 році [9]. Отже, загальна платоспроможність громадян падає, що збільшуватиме кількість бажаючих продати свій земельний наділ (чи пай) для покриття витрат домогосподарства і зменшуватиме рівень цін на земельному ринку та збільшуватиме конкуренцію серед продавців.

Згідно розділу І статті 13 Конституції України, «земля, ...., яка знаходяться в межах території України, ... є об'єктом права власності Українського народу» [1]. Проте, прийнятий Закон України «Про внесення змін до деяких законодавчих актів України щодо умов обігу земель сільськогосподарського призначення» створює реальні умови для нівелювання даного положення Конституції України [11].

Не врахована ситуація із незаконним отриманням українськими громадянами громадянства інших країн (за даними станом на 2015 рік, в Україні російські паспорти мали від 140 до 350 тисяч українців, угорські - 80-90 тисяч осіб, румунські - до 80 тисяч осіб [10]). Українські громадяни після отримання громадянства іншої країни можуть бути використані цією країною для скупівлі української землі.

У Законі ніяк не врахована наявність значної кількості українських громадян, які проживають на окупованих Російською Федерацією територіях і можуть бути залучені спецслужбами РФ до скупівлі українських сільськогосподарських земель.

Також у Законі зазначено, що право власності на земельні ділянки сільськогосподарського призначення можуть набувати банки на два роки з дня набуття права власності в порядку звернення стягнення на них як на предмет застави [11]. Не врегульовані наступні питання: чому такі земельні ділянки мають бути відчужені банками протягом двох років, а не відразу; яку господарську діяльність може вести банк і який дохід може отримувати банк під час володіння землею протягом двох років; чи $€$ ймовірність впровадження схеми передачі землі одним банком іншому банку у якості погашення міжбанківської заборгованості і чи не запускатиме це знову дворічний термін володіння землею банком (у такому випадку земля може назавжди стати банківським майном і випасти з легального обігу).

Ще одним проблемним аспектом Закону є норма про те, що площа земельних ділянок у власності однієї особи може досягати десяти тисяч гектарів. Зважаючи, що в Україні угіддя, придатні для ведення сільського господарства, складають 42,4 млн га, то, теоретично, їх можуть скупити 4240 осіб (42400 / $10=4240$ осіб). Така кількість працівників працює на більшості підприємств українських «великих підприємців» (зокрема тих, що володіють, окрім українського паспорта, ще паспортами Швейцарії, Ізраїлю, Кіпру чи інших країн). Ця потенційна кількість осіб (4240) - скупників української землі - у десятки чи сотні разів менша за кількість громадян України, що володіють паспортами інших країн (зокрема і тих, які мають територіальні претензії до України).

Висновки 3 проведеного дослідження. Таким чином, у статті здійснено теоретичне узагальнення і запропоновано практичні підходи до розв'язання наукової проблеми доцільності 
початку продажу землі в Україні в умовах економічного спаду у другій половині 2021 року, що полягає у наступному:

1. Початок продажу землі в умовах дворічної негативної динаміки економічного зростання, відсутності позитивного співробітництва з МВФ, значної інфляційної динаміки сприяє максимальному зниженню потенційної ціни на землю та вимушеному продажу землі домогосподарствами через зростання безробіття, зменшення заощаджень і кількості субсидій та збільшення цін на продукти і комунальних тарифів. Через погіршення соціально-економічної ситуації в Україні падіння потенційної вартості землі буде продовжуватись. Тому, 1 липня 2021 року як дата початку продажу землі сільськогосподарського призначення $є$ критично невдалим для продавців та країни.

2. Закон України «Про внесення змін до деяких законодавчих актів України щодо умов обігу земель сільськогосподарського призначення» прийнятий 31 березня 2020 року має бути визнаний Конституційним Судом України неконституційним або Верховна Рада України має проголосувати про втрату ним чинності і він має бути відмінений.

3. Мораторій на продаж землі сільськогосподарського призначення має бути відновлений і продаж землі - зупинений. Державні органи і експертне середовище зобов'язані спільно розробити новий, національно- та державно-орієнтований Закон про фрункціонування ринку землі, який не суперечитиме Конституції України, забезпечить належність землі, яка знаходиться у межах Державних кордонів України, українському народу та приноситиме користь всім громадянам України, а не окремим особам, які спробують нею заволодіти (наприклад, особам, подібним до тих, що за безцінь заволоділи об’єктами української промисловості у період 1991-2004 років).

\section{Література}

1. Конституція України : від 28.06.1996 р. № 254к/96-BP. URL: https://zakon.rada.gov.ua/laws/show/254\%D0\%BA/96-\%D0\%B2\%D1\%80 (дата звернення: 20.04.2021).

2. Зміна реального ВВП (у \% до відповідного кварталу попереднього року). Державна служба статистики України. URL: http://www.ukrstat.gov.ua/ (дата звернення: 04.05.2021).

3. Державний і гарантований державою борг. Незалежна асоціація банків України. URL: https://nabu.ua/ua/derzhavniy-borg-2.html (дата звернення: 20.04.2021).

4. Інформація щодо державного боргу та гарантованого державою боргу в 2019 році. Міністерство фрінансів України, опубліковано 28 січня 2020.2 URL: https://www.kmu.gov.ua/news/informaciya-shchodo-derzhavnogo-borgu-ta-garantovanogo-derzhavoyuborgu-v-2019-госі (дата звернення: 20.04.2021).

5. У лютому 2021 року державний та гарантований державою борг України знизився на 5,3 млрд грн. Міністерство фрінансів України, опубліковано 25 березня 2021 року. URL: https://www.kmu.gov.ua/news/u-lyutomu-2021-roku-derzhavnij-ta-garantovanij-derzhavoyu-borg-ukrayiniznizivsya-na-53-mlrd-grn (дата звернення: 20.04.2021).

6. Відтік іноземних інвестицій торік склав $\$ 870$ млн. Financial club, 02 квітня 2021. URL: https://finclub.net/ua/news/vidtik-inozemnikh-investitsij-torik-sklav-usd870-mln.html (дата звернення: 20.04.2021).

7. 3 початку року споживча інфляція становила 8,3\% - Держстат. УКРІНФОРМ. Мультимедійна платформа іномовлення України. URL: https://www.ukrinform.ua/rubric-economy/3278120-z-pocatku-rokuspozivca-inflacia-stanovila-83-derzstat.html (дата звернення: 04.05.2021).

8. Обух В. Субсидій "на шару" вже не буде: вимоги для отримання виплат посилюють. УКРІНФОРМ. Мультимедійна платформа іномовлення України, 19.04.2021. URL: https://www.ukrinform.ua/rubric-economy/3230752-subsidij-na-saru-vze-ne-bude-vimogi-dla-otrimannaviplat-posiluut.html (дата звернення: 20.04.2021).

9. В Україні рівень безробіття зріс майже до $10 \%$ - Центр Разумкова. УКРІНФОРМ. Мультимедійна платформа іномовлення України, 18.03.2021. URL: https://www.ukrinform.com/amp/rubric-economy/3210897-v-ukraini-riven-bezrobitta-zris-majze-do-10-centrrazumkova.html (дата звернення: 20.04.2021).

10. Романчук I. 10 фрактів і міфрів про подвійне громадянство в Україні. Мукачево.net. 28.01.2015. URL: http://www.mukachevo.net/ua/news/view/104472 (дата звернення: 20.04.2021).

11. Про внесення змін до деяких законодавчих актів України щодо умов обігу земель сільськогосподарського призначення : Закон України від 31.03 .2020 № 552-IX. URL: https://zakon.rada.gov.ua/laws/show/552-IX (дата звернення: 20.04.2021).

\section{References}

1. Verkhovna Rada of Ukraine (1996), Konstytutsiia Ukrainy [Constitution of Ukraine], Zakon Ukrainy dated 28.06.1996 no. 254k/96-VR, available https://zakon.rada.gov.ua/laws/show/254\%D0\%BA/96-\%D0\%B2\%D1\%80 (access date August 28, 2020). 
2. Change in real GDP (in\% to the corresponding quarter of the previous year). State Statistics Service of Ukraine, available at: http://www.ukrstat.gov.ua/ (access date May 04, 2021).

3. Public and state-guaranteed debt. Independent Association of Banks of Ukraine, available at: https://nabu.ua/ua/derzhavniy-borg-2.html (access date April 20, 2021).

4. Ministry of Finance of Ukraine (2020), Information on public debt and state-guaranteed debt in 2019, dated January 28, available at: https://www.kmu.gov.ua/news/informaciya-shchodo-derzhavnogoborgu-ta-garantovanogo-derzhavoyu-borgu-v-2019-roci (access date April 20, 2021).

5. Ministry of Finance of Ukraine (2021), In February 2021, Ukraine's public and state-guaranteed debt decreased by UAH 5.3 billion, dated March 25, available at: https://www.kmu.gov.ua/news/u-lyutomu2021-roku-derzhavnij-ta-garantovanij-derzhavoyu-borg-ukrayini-znizivsya-na-53-mlrd-grn (access date April 20, 2021).

6. The outflow of foreign investment last year amounted to $\$ 870$ million (2021). Financial club, available at: https://finclub.net/ua/news/vidtik-inozemnikh-investitsij-torik-sklav-usd870-mln.html (access date April 20, 2021).

7. Since the beginning of the year, consumer inflation was $8.3 \%$ - Gosstat. UKRINFORM. Multimedia platform of foreign broadcasting of Ukraine, available at: https://www.ukrinform.ua/rubric-economy/3278120z-pocatku-roku-spozivca-inflacia-stanovila-83-derzstat.html (access date May 04, 2021).

8. Obukh, V. (2021), There will be no more "layer" subsidies: the requirements for receiving payments are increasing. UKRINFORM. Multimedia platform of foreign broadcasting of Ukraine, available at: https://www.ukrinform.ua/rubric-economy/3230752-subsidij-na-saru-vze-ne-bude-vimogi-dla-otrimannaviplat-posiluut.html (access date April 20, 2021).

9. In Ukraine, the unemployment rate has risen to almost 10\% - Razumkov Center. UKRINFORM. Multimedia platform of foreign broadcasting of Ukraine, available at: https://www.ukrinform.com/amp/rubriceconomy/3210897-v-ukraini-riven-bezrobitta-zris-majze-do-10-centr-razumkova.html (access date April 20, 2021).

10. Romanchuk, I. (2015), "10 facts and myths about dual citizenship in Ukraine", Mukachevo.net. available at: http://www.mukachevo.net/ua/news/view/104472 (access date April 20, 2021).

11. The Verkhovna Rada of Ukraine (2021), The Law of Ukraine "About modification of some legislative acts of Ukraine concerning conditions of circulation of the lands of agricultural purpose", no. 552IX, dated March 31, available at: https://zakon.rada.gov.ua/laws/show/2206-19 (access date April 20, 2021). 